\title{
Screening on prenatal infections in the South and Southwest macro-regions in the State of Bahia, Brazil: detected on paper filter
}

Simone Andrade Porto São Pedro 1

iD https://orcid.org/0000-0003-1358-2460

Carlos Alberto Lima da Silva 2

iD https://orcid.org/0000-0002-8327-4271

Mônica Cardozo Rebouças 3

https://orcid.org/0000-0003-2822-5407

Maria de Fátima Dias Costa 4

iD https://orcid.org/0000-0003-0916-2893

1 Centro Estadual Especializado Em Diagnóstico, Assistência e Pesquisa. Rua Comendador José Alves Ferreira, Garcia. Salvador, BA, Brasil. CEP: 40100160. Email: simone.porto@live.com

2 Universidade Estadual de Feira de Santana. Departamento de Saúde. Feira de Santana, BA, Brasil.

3,4 Universidade Federal da Bahia. Instituto de Ciências da Saúde. Salvador, BA, Brasil.

\begin{abstract}
Objectives: to estimate the detection rate on prenatal screening pathologies on paper filter in the South and Southwest in the State of Bahia, as well as to delineate the epidemiological profile of these pregnant women, calculate and estimate the rate of adherence and the coverage of the Program.

Methods: a descriptive study was carried out from August 2013 to August 2015, and the data were obtained from the Labimuno/ICS/UFBA.

Results: 64,743 pregnant women were included; the mean ages were 25 years for the Southwest macro-region and 23 for the South. The results on the screening tests showed positivity of $0.13 \%$ and $0.29 \%$ for $\mathrm{HBs} \mathrm{Ag}, 0.17 \%$ and $0.22 \%$ for cytomegalovirus, $0.07 \%$ and $0.09 \%$ for $H C V, 0.13 \%$ and $0.38 \%$ for HTLV, $0.04 \%$ and $0.19 \%$ for HIV, $1.2 \%$ and $2.84 \%$ for syphilis, and $0.54 \%$ and $0.73 \%$ for toxoplasmosis in the Southwest and South macro-regions, respectively. The estimates on coverage were considered satisfactory. Sickle cell anemia showed positivity of $0.02 \%$ and of $0.04 \%$ and $5 \%$ and $6.3 \%$ presented sickle cell trait in the Southwest and South macro-regions, respectively.

Conclusions: the frequencies of infections in maternal-fetal health were considered low, highlighting on syphilis and the presence for sickle cell trait.

Key words Screening. Pregnancy, Vertical Transmission of Infectious Disease, Prenatal Care
\end{abstract}




\section{Introduction}

The transmission of infection from mother to child during pregnancy, labor, or through breast milk, is responsible for the increased morbidity and mortality of the mother-childbinomial, becoming a serious public health problem in Brazil.1,2 Therefore, a maternal screening on infectious diseases during the prenatal period is important for the possibility of earlier diagnoses and treatment.

The Prenatal Screening Program (PSP) on Paper Filter aims to reduce vertical transmission from screening eight pathologies: syphilis, Human immunodeficiency virus (HIV) 1 and 2, Hepatitis B and $\mathrm{C}$ Viruses (HBV and HCV, respectively), infection by Human T-Lymphotropic Virus (HTLV), Toxoplasmosis, Cytomegalovirus, Hemoglobinopathies, in a single paper filter technique, with collections made in the first and third quarters, being investigated on the first, the eight pathologies and the third, only syphilis, HIV and toxoplasmosis. ${ }^{3}$

The prenatal screening population is a strategy that may be used to track and identify inside a population of pregnant women considered at usual risk, those who are at risk of developing contagious diseases were more prevalent. Pregnant women may benefit from a further investigation to confirm and/or exclude risks, or of even immediate preventive and therapeutic actions, contributing to reduce the prevalence of these diseases and complications, as well as, maternal and child morbidity and mortality. 4

Thus, the purpose of this study was to estimate the detection rate on prenatal screening pathologies on paper filter in the South and Southwest in the State of Bahia, as well as to delineate the epidemiological profile of these pregnant women, calculate and estimate the rate of adherence and the coverage of the Program, providing health managers a better management and control and the reduction of damages on screening diseases on vertical transmission.

\section{Methods}

This is a descriptive and cross-sectional research on pregnant women who underwent prenatal screening for the Prenatal Screening Program on Paper Filter, in the South and Southwest regions in Bahia, in the period of August 2013 through August 2015. The screening included a serological investigation of seven infections (HIV, Hepatitis B, Hepatitis C, HTLV, Toxoplasmosis, Syphilis and Cytomegalovirus) and Sickle Cell Anemia, through the paper filter technique.

The pregnant woman at the beginning of the medical follow-up at her first prenatal consultation, has a routine to fill out an ID card and collect peripheral blood samples on filter paper. The paper filter technique consists on collecting blood from patients from a digital pulp or venipuncture with deposition on the paper filter in a previously outlined area. After the sample is dried (between 3 and 4 hours), the paper filter should be sent to the Immunology Laboratory by mail .

All the information used in this study were obtained directly from the Núcleo do Sistema de Processamento de Dados do Laboratório de Imunologia (Labimuno) do Instituto de Ciências da Saúde - Universidade Federal da Bahia (UFBa), (Nucleus on Data Processing System of the Immunology Laboratory (Labimuno) at the Health Science Institute) after the approval by the Ethics Committee in Research at UFBa (CAAE number: 56785816.1.0000.5662, under the document number: 1,632,313). The Labimuno integrates in the State Prenatal Screening Program on Paper Filter from the (Stork Network), from the Ministry of Health in acting areas in the cities of the South and Southwest regions in the State of Bahia.

For this study, all the pregnant womenwere included, free age range group, and, as a criterion for exclusion, pregnant women with double registrations, incomplete medical filter records information, typing mistakes, verification of the same woman with more than one pregnancy in the same year or possible abortions.

Data were collected retrospectively through the Núcleo do Sistema de Processamento de Dados do Laboratório de Imunologia do Instituto de Ciências da Saúde - UFBA (Nucleus on Data Processing System of the Immunology Laboratory at the Health SciencesInstitute), with mediate permission to use the databases.

The data were organized in worksheets containing patients' personal data (full name, date of birth, race/color, address, telephone number, the SUS card number); gestational data (date of last menstrual period, number of pregnancies including number of childbirth, natural birth, cesarean and abortions, gestation time in weeks) and data registration from the data program (number of the medical record, performance unit, date and period on collecting blood on paper filter).

The variables selected included cities of origin, age, gestation quarter at the collecting period for the examination, number/types of childbirth and screening illness. The age variable was organized 
into six age groups: I ( 9 to 10 years old), II (10 to 14 years old), III (15 to 19 years old), IV (20 to 24 years old), V (25 to 29 years old) and VI (over 30 years old).

The data were typed in the SPSS version 20.0 program (Chicago, USA), the statistical study was descriptive with percentages. For the analysis of categorical qualitative variables were estimated simple frequencies and for the quantitative variables estimated measures were of the central tendency (mean and median).

\section{Results}

The Southwest macro-region comprises a total of 73 cities with a total of $1,812,416$ inhabitants, while the South macro-region is composed of 67 cities, totaling 1,692,494 inhabitants, according to DATASUS. 5 The macro-regions were discontinued and the Distritos Regionais de Saúde (DIRES) (Regional Health Districts) has been extinct since December 11, 2014 under the Law Number. 13,204 and to substitute, the Núcleos Regionais de Saúde (NRS) in which it was created.

64,743 pregnant women were included, being $34,837(53.8 \%)$ and $29,906(46.2 \%)$ from the Southwest and South macro-regions in Bahia, respectively. 549,401 screening tests were carried out, being 298,573 (54.3\%), in the Southwest macroregion, and $250,828(45.7 \%)$, in the South macroregion. Of the total number of pregnant women included in the Southwest macro-region, all of them performed the first collection and 16\% the second. In the South macro-region, all of them performed the first collection and $11.5 \%$ on the second, the total of pregnant women included.

The stratification of the examinations showed 32,055 were performed in 2013, 118,807 in 2014 and 99,966 corresponding to the period between January and August of 2015, in the South macro-region. In the Southwest macro-region, the examinations were performed by pregnant women which represented 35,424 in 2013, 150,194 in 2014 and 112,955 were assessed during eight months in 2015 .

In relation to age range, $0.03 \%$ pregnant women were included up to 9 years old, $3.9 \%$ between 10 and 14 years old, $23.7 \%$ between 15 and $19,25.3 \%$ between 20 and $24,19.3 \%$ between 25 and 29, and $27.5 \%$ over 30 years old in the Southwest macroregion, showing a median of 25 years of age. In South macro-region, $0.03 \%$ were pregnant women below 10 years old, $6.5 \%$ between 10 and 14, 29.4\% between 15 and $19,25.9 \%$ between 20 and 24 , $16.8 \%$ between 25 and 29 and $20.9 \%$ over 30 years, with a median of 23 years of age. In regard to the gestational age, in the South macro-region, $36.9 \%$ pregnant women were in their first trimester of pregnancy, $40.5 \%$ in their second and $22.6 \%$ in their third. In relation to the number of childbirths that was informed, $31.7 \%$ already had natural childbirths and $10.1 \%$ had cesarean sections. The percentage of abortions was $15.7 \%$. Among all the pregnant women included in the Southwest macro region, $48.8 \%$ were in their first trimester of pregnancy, $33.6 \%$ in their second and $17.6 \%$ in their third. In relation to the number of childbirths, $31.9 \%$ had natural childbirths and $11.1 \%$ had cesarean sections. The percentage of abortions presented was $13.5 \%$ (Table 1).

During the period of 2013 to 2015 , the screening tests results for the Southwest macro-region showed positivity of $0.13 \%$ for Hepatitis B, $0.17 \%$ for Cytomegalovirus, $0.07 \%$ to $0.13 \%$ for Hepatitis C, HTLV, $0.04 \%$ for HIV, $1.2 \%$ for syphilis and $0.54 \%$ for toxoplasmosis. At the same period, the screening tests results for the South macro-region, showed positivity of $0.29 \%$ for Hepatitis B, $0.22 \%$ for Cytomegalovirus, $0.09 \%$ for Hepatitis C, $0,38 \%$ for HTLV, $0.19 \%$ for HIV, $2.84 \%$ for syphilis and $0.73 \%$ for toxoplasmosis (Table 2).

The estimated coverage on Prenatal Screening Program on Paper Filter was calculated taking in consideration the number of live births in the previous year, which was available in the Sistema de Informações sobre Nascidos Vivos (SINASC) (Information System on Live Births), mounting by $10 \% .6$ In the Southwest macro-regions, $84 \%$ of health coverage was found in the region of Brumado, 69\% in Guanambi, $89 \%$, in Itapetinga and $60 \%$ in Vitória da Conquista (Figure 1). In the South macro-region, the health region in Ilhéus showed a range of $59 \%, 53 \%$ in Itabuna, $45 \%$ in Jequié and $76 \%$ in Valença (Figure 2).

The screening test results for sickle cell anemia showed positivity of $0.02 \%$ for this disease and $5.44 \%$ presented sickle cell traitin the Southwest macro-region. In the South macro-region, $0,05 \%$ was found with sickle cell anemia and $8.52 \%$ presented sickle cell trait. More than $90 \%$ of the studied population presented exams with normal results, and less than $0.5 \%$ of the pregnant women did not perform this examination in both regions (Table 3 ).

\section{Discussion}

The screening on pathologies that may affect pregnant women is an important tool for the formulation of policies on maternal-fetal health. Regarding to the 
Table 1

Distribution of data on pregnant women by macro-region.

\begin{tabular}{|c|c|c|c|c|}
\hline \multirow{3}{*}{ Variables } & \multicolumn{4}{|c|}{ Macro-region } \\
\hline & \multicolumn{2}{|c|}{ Southwest } & \multicolumn{2}{|c|}{ South } \\
\hline & $\mathrm{n}$ & $\%$ & $\mathrm{n}$ & $\%$ \\
\hline Pregnant women & 34,837 & 100.0 & 29,906 & 100.0 \\
\hline Age (in years, median, IQ) & \multicolumn{2}{|c|}{$25[20-30]$} & \multicolumn{2}{|c|}{$23[19-28]$} \\
\hline \multicolumn{5}{|l|}{ Age group range } \\
\hline Between 9 and 10 years old & 13 & 0.1 & 10 & 0.03 \\
\hline Between 10 and 14 years old & 1,369 & 3.9 & 1,942 & 6.5 \\
\hline Between 15 and 19 years old & 8,254 & 23.7 & 8,807 & 29.5 \\
\hline Between 20 and 24 years old & 8,802 & 25.3 & 7,721 & 25.9 \\
\hline Between 25 and 29 years old & 6,732 & 19.4 & 5,026 & 16.8 \\
\hline Over 30 years old & 9,593 & 27.6 & 6,251 & 21.3 \\
\hline Not informed & 74 & 0.27 & 149 & 0.47 \\
\hline Gestational Age in the 1 st & & & & \\
\hline \multicolumn{5}{|l|}{ examination collection } \\
\hline First Trimester & 15,057 & 48.8 & 9,686 & 36.9 \\
\hline Second Trimester & 10,370 & 33.6 & 10,869 & 40.5 \\
\hline Third Trimester & 5,418 & 17.6 & 4,998 & 22.6 \\
\hline \multicolumn{5}{|l|}{ Childbirth } \\
\hline \multicolumn{5}{|l|}{ Normal } \\
\hline 1 & 6,518 & 18.7 & 5.508 & 16.9 \\
\hline 2 or more & 4,729 & 13.2 & 4.401 & 14.8 \\
\hline \multicolumn{5}{|l|}{ Cesarean } \\
\hline 1 & 3,239 & 9.3 & 2.372 & 7.9 \\
\hline 2 or more & 652 & 1.8 & 672 & 2.2 \\
\hline \multicolumn{5}{|l|}{ Abortion } \\
\hline 1 & 5,566 & 16.0 & 5.072 & 17.8 \\
\hline 2 or more & 29,271 & 84.0 & 24.834 & 83.0 \\
\hline
\end{tabular}

Table 2

Frequency of screening infections in pregnant women in the studied macro-regions.

\begin{tabular}{|c|c|c|c|c|}
\hline \multirow{3}{*}{ Infections } & \multicolumn{4}{|c|}{ Macro-region } \\
\hline & \multicolumn{2}{|c|}{ Southwest } & \multicolumn{2}{|c|}{ South } \\
\hline & $\mathrm{n}$ & $\%$ & $\mathrm{n}$ & $\%$ \\
\hline HBsAg & 135 & 0,2 & 93 & 0,29 \\
\hline CMVM & 126 & 0,19 & 69 & 0,22 \\
\hline $\mathrm{HCV}$ & 52 & 0,08 & 30 & 0,09 \\
\hline HTLV & 165 & 0,25 & 120 & 0,38 \\
\hline HIV & 82 & 0,10 & 69 & $0,1 \mathrm{c}$ \\
\hline Syphilis & 1410 & 1,87 & 1011 & 2,84 \\
\hline Toxoplasmosis & 442 & 0,59 & 261 & 0,73 \\
\hline
\end{tabular}

$\mathrm{n}=$ number, $\mathrm{HBsAg}=\mathrm{Hepatitis} \mathrm{B}$ virus surface antigen, $\mathrm{CMVM}=\mathrm{Cytomegalovirus,} \mathrm{HCV=Hepatitis} \mathrm{C}$ virus, HTLV = Human T-lymphotropic virus, HIV= Acquired Immunodeficiency Virus. 


\section{Figure 1}

Coverage estimation on the Prenatal Screening Program, on paper filter, by health regions of the Southwest macro-regions in Bahia.

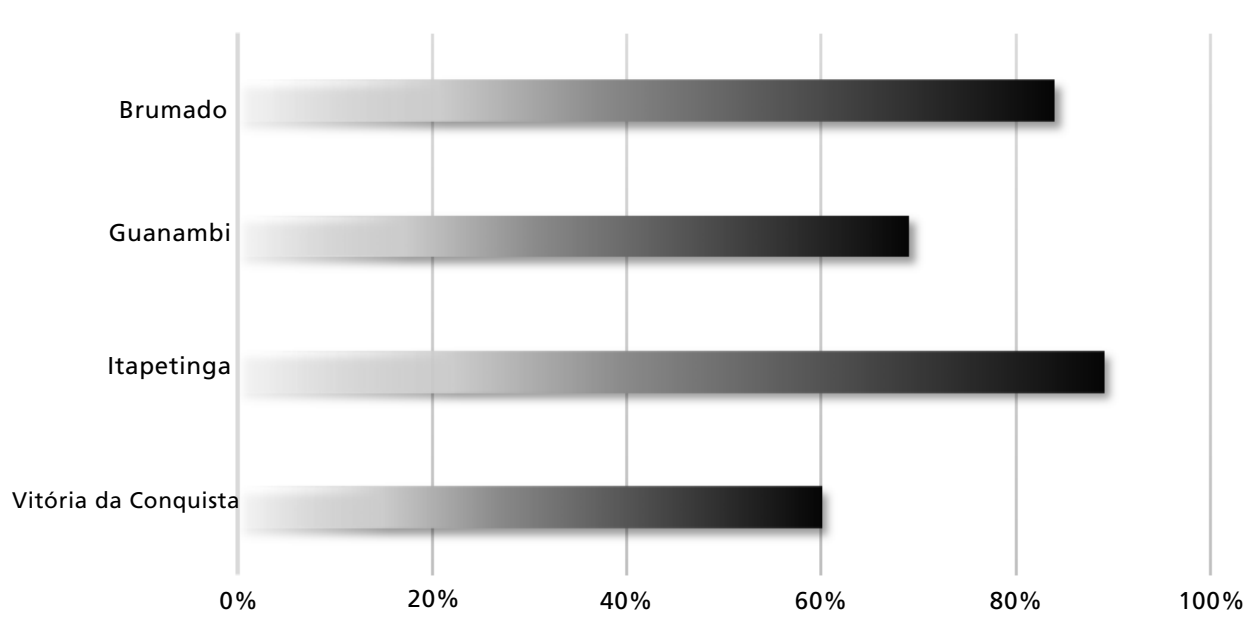

Figure 2

Coverage estimation on the Prenatal Screening Program, on paper filter, by health regions of the South macro-regions in Bahia.

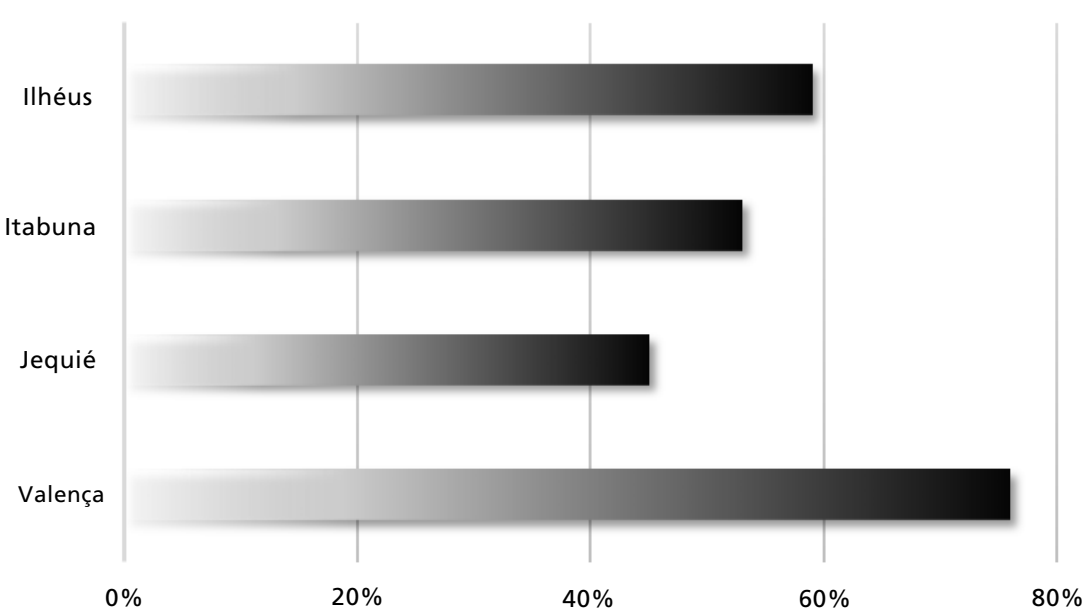


Screening test for sickle cell anemia in pregnant women from the Southwest and South macro-regions in the State of Bahia, by High Performance Liquid Chromatography (HPLC).

\begin{tabular}{lcccccc}
\hline \multirow{2}{*}{ Variables } & \multicolumn{2}{c}{ Southwest Macro-region } & \multicolumn{2}{c}{ South Macro-region } & \multicolumn{2}{c}{ Total } \\
\cline { 2 - 7 } & $\mathrm{n}$ & $\%$ & $\mathrm{n}$ & $\%$ & $\mathrm{n}$ & $\%$ \\
\hline Normal Exam & 32,901 & 94.12 & 27,500 & 91.25 & 60,401 & 92.82 \\
Sickle Cell Anemia & 7 & 0.02 & 14 & 0.05 & 21 & 0.03 \\
Sickle Cell Trait & 1,790 & 5.44 & 2,343 & 8.52 & 4,133 & 6.84 \\
Not performed & 139 & 0.42 & 49 & 0.18 & 188 & 0.31 \\
Total & 34,837 & 100.0 & 29,906 & 100.0 & 64,743 & 100.0 \\
& & & & & & \\
\hline
\end{tabular}

prospect of vertical infections, this screening is mandatory and must be accomplished on the first prenatal consultation. The use of paper filter for screening on pregnant women has shown to be quite effective, both in economic, as biosecurity and reliability aspects. 6 In this study, it was sought to estimate the rate of early detection of pathology screening, through the use of paper filter, as well as the coverage on adhesion and scope on the Programa de Triagem Pré-natal em Papel de Filtro da Rede Cegonha (Prenatal Screening Program on Paper Filter from the Stork Network), in the South and Southwest macro-regions in the State of Bahia. In addition, there was a concern to trace these pregnant women's epidemiological profile on the screening program.

The studied macro-regions presented similarities in the number of cities, number of pregnant women, and examinations performed were included in the study. The pregnant women's median age was 25 years old, with an age range variation of 9 to over 30 years old. Most women, from both macro-regions, were over 19 years of age. This corroborates statistical data of the civil registry from the Instituto Brasileiro de Geografia e Estatística (IBGE), (Brazilian Geography and Statistics Institute), ${ }^{7}$ demonstrating that Brazilian women have children in a later age. The survey performed by the Institute shows that pregnancy between 15 and 19 years of age, in Brazil, decreased from $20.4 \%$ to $17.7 \%$ between 2002 to 2012. Besides, the number of women over 30 years of age who got pregnant increased from $22.4 \%$ to $30 \%$ between 2000 and 2014. This behavioral change may be related to an increase in the women's educational level, greater opportunities for employment and a decrease on birth rates.
According to the Programada Rede Cegonha (Stork Network Program), all the pregnant women should perform a first collection of examinations in their first quarter, and a second collection, in their third trimester of pregnancy. However, this study has shown that only $19 \%$ and $13 \%$ of the pregnant women performed the second collection of examinations, in the Southwest and South macro-regions, respectively.

This data may be attributed to the lack of information/awareness of the pregnant women as well, as the lack of health professionals, which may be the cause, and among other factors, as changes in the coordination, substitutions of professionals and the lack of adequate training. ${ }^{8}$ Pregnant women who arrived between the second and third trimester, in most cases only performed the first collection. This was observed in $54.4 \%$ and $63.1 \%$ of the population in the Southwest and South macro-regions, respectively. This is an important data because pregnant women who performed the examination collection in the first quarter have the opportunity for early detection of diseases, covering the immunological duration until the period for the second collection, in the third quarter. While pregnant women perform only one examination collection are at risk in becoming infected during their pregnancy without any diagnosis and treatment, in addition to a false negative result. It is worth mentioning that, regardless of the gestational trimester, the pregnant women will perform the first examination collection at the health unit. ${ }^{9}$

In relation to the performance of the second examination, as advocated by the Ministry of Health, we observed that between 11 and $16 \%$ of the pregnant women make more than one examination collection. These findings are according to 
Domingues et al. 10 findings that emphasized in all the Brazilian regions, there is high adhesion to the first test and low adhesion to the second testing $(<30 \%)$. For this matter, this study has highlighted problems to implement the recommendations for the second testing during prenatal care in the studied macro-regions.

Although there is a rapid test to diagnose syphilis and have early treatment, but this illness is still considered as a public health problem. ${ }^{11}$ In Brazil, a prevalence of $1.02 \%,{ }^{11}$ was found, however, in this study, the observed results revealed a high level of screening among pregnant women, with a detection rate of $1.87 \%$ and $2.84 \%$, in the Southwest and South macro-regions, respectively, higher than the national index. These indexes may be associated with low maternal schooling, the use of alcohol and/or drugs, multiple sexual partners and difficulty to access and have accessibility to primary care in prenatal care. 12 In addition to these factors, from 2010 syphilis is an obligatory notable disease, in which may have caused an increase in the number of reported cases. 13 Note that the lack of monitoring pregnant women who were positive for syphilis, flaws in their medical records and/or prenatal cards also contribute to the permanency of syphilis in this population. 13

In relation to toxoplasmosis, this was the second most common infection in the studied population. The prevalence of toxoplasmosis may vary among individual adults. 14 These variations may occur due to the difference of exposure to major sources of infection and regional variability in the incidence of this disease and also the specific characteristics of the studied population, which demonstrates the importance of epidemiological data collection from various regions, in order to improve the strategies that meet the necessity of each reality. 14

Our study presented a prevalence of IgM antibodies of $0,54 \%$ and $0,73 \%$ in the South and Southwest macro-regions, respectively. These findings are similar to the prevalence of $0,8 \%$ found in pregnant women in the State of Bahia. 15

In Brazil, it is estimated that approximately $0,38 \%$ of the pregnant women are infected with HIV. ${ }^{10}$ In the present study, we found a frequency rate of infection for HIV of 0,1 in the Southwest macro-region and $0,19 \%$ in the South macro-region. These data corroborates with Santos et al. ${ }^{16}$ findings which a prevalence of $0,1 \%$ was found in Salvador, the capital of Bahia.

Gouveia, Silva e Albuqueque 17 showed that the rate of vertical transmission in the Northeast region is $9,2 \%$. This data emphasizes the importance of prenatal care in detecting infected pregnant women in order to provide effective interventions that may prevent vertical transmission. ${ }^{1}$

In Brazil, the prevalence of infection by $\mathrm{HCV}$ among pregnant women varies from $0,9 \%$ to $1,5 \% .17$ In this study, we found the infection frequency of $\mathrm{HCV}$ of $0,07 \%$ in the Southwest macro-region and $0,09 \%$ in the South macro-region, however this low rate is not against the possibility of vertical transmission, and the monitoring routine should continue during prenatal care. And also we should consider the $\mathrm{HCV}$ underreporting rates. Vertical transmission of $\mathrm{HCV}$ is estimated at $5-10 \%$, and may vary due to high viral load, invasive monitoring and prolonged labor. 18 Thus, screening on pregnant women may allow better obstetric care in order to minimize the transmission.

Vertical transmission of HBV is the main cause of chronic infection in endemic areas. The prevalence of hepatitis B in pregnant women worldwide is 0,25 to $1,5 \%$, which may vary depending on the geographical region, as well as the population under study. 19 The obtained results showed that a frequency of positive AgHBs results among pregnant women is low in relation to the Southwest macroregion, of $0,13 \%$, but close to the frequency found in the South macro-region, of $0,29 \%$.

In relation to HTLV, Bahia is considered an endemic area for this infection, affecting approximately $2 \%$ of the general population in the State. 20 In this study, a frequency of $0.17 \%$ and $0.22 \%$ was found in the Southwest and South macro-regions, respectively. A study conducted in the city of Salvador, Bahia, found a prevalence rate of $0.84 \% .21$ In addition, it was observed that epidemiological data for HTLV-positive mothers suggested vertical transmission as a more frequent means of HTLV-I transmission. 21

Congenital infection caused by cytomegalovirus is considered one of the most common congenital infections worldwide, with a prevalence of 0.2 to $2.2 \% .22$ Similar values were found in this study, where the total frequency (in the Southwest and South macro-regions) was of $0.3 \%$. The diagnostic on early infection is fundamental since intrauterine transmission of the virus occurs in $30 \%$ to $40 \%$ of the pregnancies in women with primary infection and there is no effective therapy for this infection, despite advances in the diagnosis. 22

Although the South macro-region had a lower number of pregnant women included in the study, in which presented a lower mean on gestational age (29.5\% of the pregnant women were between 15 and 19 years old), lower number on the second examina- 
tion collection $(11.5 \%)$ and a greater number of infections screened at prenatal care. This region has some similar characteristics, such as: it has coastal cities and cities that are among the ten most populous in the State (as for example, the city of Itabuna). In addition, all of the cities have economic and commercial relevance and, in some, intense touristic activities. The higher mean rates of incidence found in these regions (mainly for syphilis) may be explained by the studies that report the occurrence of a higher concentration of cases in the coastal cities and in those which have large metropolitan areas and intense commercial activity, due to the dynamics in human relations. ${ }^{23}$

Sickle cell anemia is the highest prevalence hereditary disease in the country and is present mainly in the black population, but it is also observed in the Caucasian population due to a high rate of miscegenation and is considered an important public health problem in the Brazilian regions. 24 In this study, we found a total frequency of $0.03 \%$ of pregnant women with sickle cell anemia and $6.3 \%$ presented the sickle cell trait.

During the pregnancy, sickle cell anemia is associated with an increased risk of multiple maternal and fetal complications. 25 Although maternal and perinatal mortality rates are low due to this disease, prenatal screening is important to monitor these patients, as well as to ensure a better follow-up during the pregnancy. In addition, the newborn's diagnosis is important because it may allow an appropriate approach in the first years of life and genetic counseling by reducing the complications due to the disease. 26

Botelho et al. 1 found a rate similar to this study in relation to individuals with sickle cell trait (5.5\%). The sickle cell trait is a relatively common and clinically benign condition, but it can also be transmitted to the offsprings. The high frequency rate of the sickle cell trait found highlights the need for early diagnostic programs and as for, genetic, social and psychological counseling for couples and individuals with sickle cell trait. It is fundamental an awareness on reproductive risk in generating children with sickle cell disease. ${ }^{26}$

In relation to the estimated coverage of the screening program, in 2014 , it reached $59 \%$ in the Health region in Ilhéus; $53 \%$ in Itabuna; $45 \%$ in Jequié and $76 \%$ in Valença for the South macroregion. In the Southwest macro-region, in the Health region in Brumado, a coverage rate of $84 \%$ was found; $69 \%$ in Guanambi; $89 \%$ in Itapetinga and $60 \%$ in Vitória da Conquista. A better coverage rate is observed in the Southwest macro-region, with a mean of $75.5 \%$, compared to $58.2 \%$ in the South macro-region. In a study conducted by Botelho et $a l .1$, in the State of Mato Grosso de Sul, variations were also found in the coverage rate among the cities included in the evaluation of the program to protect the pregnant women, ranging from 60 to $100 \%$.

In the case of a relatively recent implementation of a program, the compliance with more concrete results is limited, since it includes an articulated set of interventions, difficulty in controlling the influence of real conditions in which the programs are developed, the capacity, the regular training and monitoring which can improve the coverage. 27,28 Thus, these variations in coverage estimates may be due to high professional turnover (much more frequent in the countryside, mainly because it involves personnel indications by political criteria and it is not always stable), organizational and/or operational weaknesses, inadequate professional training, lack of technical and management capacity, and among others. 28 The effectiveness on basic care will possibly lead the pregnant women in arriving earlier for testing, enabling a new examination collection in the third trimester by eliminating the immunological risk.28,29

Prenatal care, when offered with quality, it is understood as availability of adequate infrastructure in terms of physical, material, human and financial resources, multidisciplinary care, guidelines and behaviors that meet the need for each pregnant woman. Thus, it is understood that are for pregnant women should be based not only on clinical procedures, but on a set of actions such as health promotion, welcoming, bonding, and among others, in order to develop the women's autonomy for their self-care.

Although access to prenatal care reaches practically the entire population, the quality of this care is still unsatisfactory since educational activities in health do not address the reproductive and sexual needs for women and men and the service network on diagnostic support to perform the recommended tests during pregnancy, nor does it contemplate the need in the cities, in addition to exist in several locations for woman to find care at the health establishment at the moment of the childbirth and birth. 29

Screening programs for pregnant women are of extreme importance to reduce vertical transmission, with care assistance for pregnant women (prenatal) and for all the newborns born of mothers with the disease. The use of paper filter for screening pregnant women has shown to be quite effective, both in terms of economic, reliability and biosafety aspects. It is an inexpensive and convenient method for 
collecting, storing, transporting, handling and preserving for long periods of blood samples to be used in population studies and in serological screening programs. Such advantages have been demonstrated by the experience and results of neonatal screening programs over the last 40 years for a large group of pathologies. 6

In the present study, it was verified that the frequencies of the infections, detected on paper filter, in pregnant women in the two studied regions in general were compatible with those found in other regions of the country, except for syphilis and the presence of sickle cell trait which presented a higher percentage. In addition, due to the implementation phase of the Programa da Rede Cegonha (Stork Network Program) and considering the fact that the data represents its initial phase, demanding expansion and consolidation in order to achieve better results, coverage rates in the South and Southwest macro-regions in Bahia were considered satisfactory. However, the second screening test for both diseases was not performed by most of the pregnant women, evidencing a low adherence to the recommendations in care, since prenatal care had begun late. As examination collection in the first and third trimesters of gestation during the prenatal period is recommended, the late arrival of the pregnant woman at the health unit does not allow the second examination collection to be performed.

Vertical transmission infections and sickle cell anemia are still public health problems in the State of Bahia. The frequencies of infections detected in pregnant women in the two studied regions reflect important significant measures to be adopted in the public health area. It is worth mentioning that partners' participation is fundamental, through the Rede Cegonha (Stork Network) and the Estratégia PréNatal do Parceiro do Ministério da Saúde (Partner's Prenatal Strategy of the Ministry of Health), aiming for the interruption of chain transmission and access to information.

\section{Authors' Contributions}

São Pedro SAP - method structure, data collecting, article writing and critical intellectual review. Silva CAL - data analysis and interpretation. Rebouças MC - data collecting, article writing and critical intellectual review of the manuscript. Costa MFD hypothesis of the article; mentored the article; got partnerships to accomplish the article, critical intellectual review of the manuscript. All authors approved the final version of the manuscript.

\section{References}

1. Botelho CAO, Tomaz CAB, Cunha RV, Botelho MAO, Botelho LO, Assis DM, Pinho DLM. Prevalência dos agravos triados no programa de proteção à gestante do estado de Mato Grosso do Sul de 2004 a 2007. Rev Patol Trop. 2008; 37 (4): 341-53.

2. Brasil. Ministério Da Saúde. Atenção ao pré-natal de baixo risco. Brasília, DF, 2012. p. 318

3. Brasil. Ministério da Saúde. Portaria no 1.459 , de 24 de junho de 2011. Institui no âmbito do Sistema Único de Saúde-SUS a Rede Cegonha. Diário Oficial da União [DOU]. Brasília, DF; 2011. p.18-21.

4. Wald NJ. Guidance on terminology. J Med Screen. 1994; 15 (1): 50 .

5. Brasil. Departamento de Informática do SUS (DATASUS). Informações de Saúde, Demográficas e Socioeconômicas: banco de dados. [acesso em 01 jul 2019]. Disponível em: http://tabnet.datasus.gov.br/cgi/tabcgi.exe?ibge/cnv/poptba. def

6. Boa-Sorte N, Purificação A, Amorim T, Assunção L, Reis A, Galvão-Castro B. Dried blood spot testing for the antenatal screening of HTLV, HIV, syphilis, toxoplasmosis and hepatitis B and C: Prevalence, accuracy and operational aspects. Braz J Infect Dis. 2014; 18 (6): 618-24.

7. IBGE (Instituto Brasileiro de Geografia e Estatística). Estatísticas do registro civil. 2014; 41: 1-82.

8. Cotta RMM, Schott M, Azeredo CM, Franceschini SCC, Priore SE, Dias G. Organização do trabalho e perfil dos profissionais do Programa Saúde da Família: um desafio na reestruturação da atenção básica em saúde. Epidemiol e Serv Saúde. 2006; 15 (3): 7-18.

9. Brasil. Ministério da Saúde. Secretaria de Vigilância em Saúde. Diretrizes para controle da sífilis congênita: Manual de bolso. Coleção DST. AIDS - Série. Manuais. Brasília, DF; 2006. p.72

10. Domingues RMSM, Szwarcwald CL, Souza PRB, Leal MDC. Prenatal testing and prevalence of HIV infection during pregnancy: data from the "Birth in Brazil" study, a national hospital-based study. BMC Infect Dis. 2015; 15 (1): $1-11$.

11. Vargas L, Amaral S, Arriaga M, Sarno M, Brites C. High prevalence of syphilis in parturient women and congenital syphilis cases in public maternities in Salvador-Bahia, Brazil. BJOG. 2018; 125 (10): 1212-14. 
12. Garbin AJI, Martins RJ, Belila NM, Exaltação SM, Garbin CAS. Reemerging diseases in Brazil: sociodemographic and epidemiological characteristics of syphilis and its under-reporting. Rev Soc Bras Med Trop. 2019; 52 (e20180226): 1-4.

13. Torgerson PR, Mastroiacovo P. The global burden of congenital toxoplasmosis: a systematic review. Bull World Health Organ. 2013; 91 (7): 501-8.

14. Costa GB, de Oliveira MC, Gadelha SR, Albuquerque GR, Teixeira M, Raiol MRS, Sousa SMB, Marin LJ. Infectious diseases during pregnancy in Brazil: seroprevalence and risk factors. J Infect Dev Ctries. 2018; 12 (8): 657-65.

15. Brasil. Ministério da Saúde. Secretaria de Vigilância em Saúde. Departamento de DST A e HV. Manual técnico para o diagnóstico da infecção pelo HIV. Brasília, DF; 2013. p.555 .

16. Gouveia PAC; Silva GAP; Albuquerque MFPM. Factors associated with mother-to-child transmission of the human immunodeficiency virus in Pernambuco, Brazil, 20002009. Trop Med Int Heal. 2013; 18 (3): 276-85.

17. Ward C, Tudor-Williams G, Cotzias T, Hargreaves S, Regan L, Foster GR. Prevalence of hepatitis C among pregnant women attending an inner London obstetric department: uptake and acceptability of named antenatal testing. Gut. 2000; 47 (2): 277-80.

18. Mishra S, Purandare P, Thakur R, Agrawal S, Alwani M Study on prevalence of hepatitis B in pregnant women and its effect on maternal and fetal outcome at tertiary care centre. 2017 ; 6 (6): 2238-40

19. Brites C; Weyll M; Pedroso C; Badaró R. Severe and Norwegian scabies are strongly associated with retroviral (HIV-1 / HTLV-1) infection in Bahia, Brazil. AIDS. 2002; 16 (9): 1292-3.

20. Bittencourt AL, Dourado I, Filho PB, Santos M, Valadao E, Alcantara LC, Galvão-Castro B. Human T-cell lymphotropic virus type 1 infection among pregnant women in northeastern Brazil. J Acquir Immune Defic Syndr. 2001. 26 (5): 490-4.

Received on June 28, 2017

Final version presented on April 19, 2019

Approved on June 28, 2019
21. Serra FC, Machado J, Nicola MH, Claudia M, Jorge MCS, Cruz LE, Giordano MV, Silva RO. Soroprevalência de citomegalovírus em gestantes brasileiras de classe socioeconômica favorecida. J Bras Doenças Sex Transm. 2009; 21 (1): 12-5.

22. Yinon Y, Farine D, Yudin MH, Gagnon R, Hudon L, Basso $\mathrm{M}$, et al. Cytomegalovirus Infection in Pregnancy. J Obstet Gynaecol Canada. 2010; 32 (4): 348-54.

23. Szwarcwald CL, Bastos FI, Esteves MAP, Andrade CLT. A disseminação da epidemia da AIDS no Brasil, no período de 1987-1996: uma análise espacial. Cad Saúde Pública. 2000; 16 (1): 07-19.

24. Silva-Pinto AC, Ladeira SOD, Brunetta DM, Santis GC, Angulo IL, Covas DT. Sickle cell disease and pregnancy: Analysis of 34 patients followed at the Regional Blood Center of Ribeirão Preto, Brazil. Rev Bras Hematol Hemoter. 2014; 36 (5): 329-33.

25. Silva FA, Ferreira AL, Hazin-Costa MF, Dias ML, Araújo AS, Souza AI. Adverse clinical and obstetric outcomes among pregnant women with different sickle cell disease genotypes. Int J Gynecol Obstet. 2018; 143 (1): 89-93.

26. Rance JC, Skirton H. An integrative review of factors that influence reproductive decisions in women with sickle cell disease. J Community Genet. 2019; 10 (2): 161-9.

27. Santos M, Silvino ZR. A Construção do Modelo Atual de Avaliação em Serviços de Saúde: Análise Reflexiva. Rev Enferm UFPE on line. 20159 (9): 9306-14

28. Medeiros C, Junqueira A, Schwingel G, Ioná C, Jungles L, Lechmann O. A rotatividade de enfermeiros e médicos: um impasse na implementação da Estratégia de Saúde da Família. Ciên Saúde Colet. 2005; 15 (Supl.1): 1521-31.

29. Santos SMP, Santos LV, Rodrigues JO, Santos LC, Souza LB, Silva UB. Acessibilidade ao Serviço de Saúde da Mulher no Ciclo Gravídico. Cogitare Enferm. 2016; 21 (1): $1-10$ 